\title{
PENDIDIKAN KESEHATAN TENTANG JAPANESE ENCEPHALITIS BERPENGARUH PADA TINGKAT PENGETAHUAN SISWA SEKOLAH DASAR DI CANGGU, BALI
}

\author{
Ni Made Ari Sukmandari \\ Dosen STIKes Bina Usada Bali \\ Korespodensi penulis: arisukmandarimd@gmail.com
}

\begin{abstract}
Abstrak
Latar belakang dan tujuan: Japanese Encephalitis (JE) adalah penyakit radang otak yang disebabkan oleh virus Japanese encaphaitis dan ditularkan oleh nyamuk Virus JE memerlukan hewan sebagai inang perantara seperti babi dan beberapa spesies burung. Imunisasi merupakan cara yang paling efektif untuk mencegah JE pada manusia. Selain imunisasi JE sebagai salah satu pencegahan penyakit, tentunya tidak terlepas dengan edukasi dan penyuluhan sebagai pencegahan penyakit JE. Penelitian ini ingin mengetahui pengaruh pendidikan kesehatan tentang Japanese Encephalitis (JE) terhadap tingkat pengetahuan siswa sekolah dasar di Desa Canggu.

Metode: Rancangan penelitian ini merupakan Pre-Experimental dengan desain the one group pretest posttest design. Pengambilan sampel dilakukan dengan cluster random sampling. Analisa data yang digunakan dalam penelitian ini adalah Uji Wilcoxon.

Hasil: Hasil penelitian diperoleh pengetahuan responden sebelum diberikan pendidikan kesehatan tentang Japanese Encephalitis memiliki pengetahuan kurang yaitu sebanyak 40 responden $(61,5 \%)$ dan pengetahuan baik setelah diberikan pendidikan kesehatan tentang Japanese Encephalitis yaitu sebanyak 40 responden (61,5\%). Hasil uji Wilcoxon diperoleh nilai p value $0,014<0,05$.

Simpulan: ada pengaruh pengetahuan tentang JE sebelum dan sesudah diberikan pendidikan kesehatan tentang Japanese Encephalitis.
\end{abstract}

Kata kunci: Japanese Encephalitis, Tingkat Pengetahuan, Pencegahan

\section{Pendahuluan}

Japanese Encaphalitis (JE) adalah penyakit radang otak (encaphalitis) yang disebabkan oleh virus Japanese encaphaitis dan ditularkan oleh nyamuk. Manusia dapat tertular virus JE jika digigit oleh nyamuk Culex yang terinfeksi virus JE. Virus JE memerlukan hewan sebagai inang perantara seperti babi dan beberapa spesies burung. Nyamuk Culex tersebut berkembang biak di tempat genangan air seperti sawah, kolam dan menggigit terutama pada malam hari (Kemenkes, 2017). Sekitar 16-30\% kasus JE dapat menyebabkan kematian. Angka kematian yang tinggi terjadi pada anak khususnya anak berusia di bawah dari 10 tahun. Gejala klinis JE umumnya normal 414 hari setelah infeksi antara lain demam mendadak, penurunan kesadaran, sakit kepala, kesulitan berbicara, berjalan ataupun gangguan motorik lainnya dan kejang terutama pada anak.

Penyakit ini pertama dikenal pada tahun 1871 di Jepang, diketahui menginfeksi sekitar 6000 orang pada tahun 1924 kemudian terjadi KLB dari tahun 1946-1950. Penyakit ini endemik di daerah Asia, mulai dari Jepang, Filipina, Taiwan, Korea, China, Thailand, Malaysia, Indonesia dan India. Diperkirakan ada 35.000 kasus JE tiap tahunnya di Asia. Di Indonesia, virus JE pertama disolasi dari nyamuk pada tahun 
1977 di daerah Bekasi. Pada tahun 2005 dilaporkan bahwa terjadi infeksi JE pada berbagai tempat di Indonesia, berdasarkan hasil surveilans berbasis rumah sakit di enam provinsi di Indonesia tahun 2005-2006 mengatakan bahwa Indonesia merupakan daerah endemis JE dimana persentase positif $\mathrm{Ab} \mathrm{JE}$ berkisar antara 1,8\% hingga 17,9\% (Ompusunggu et al, 2008).

Di Bali, penyakit JE mengalami peningkatan tiap tahunnya. Hal ini dapat dilihat dari data surveilans Dinas Kesehatan Provinsi Bali yang mengatakan bahwa kasus klinis JE pada tahun 2014 sebanyak 55 kasus dan semakin meningkat pada tahun 2015 mencapai 208 kasus. Pada tahun 2014 kasus klinis JE menyebar di delapan kabupaten yang ada di Bali. Pada tahun 2015 kasus klinis JE terus mengalami peningkatan di masing-masing kabupaten. Salah satu daerah yang mengalami KLB JE adalah Desa Canggu, Kabupaten Badung. KLB ini terjadi pada bulan November 2015 tepatnya di Banjar Canggu, Desa Canggu. Daerah ini merupakan daerah dengan kasus klinis JE terbanyak selama tahun 2015 yaitu sebanyak 18 kasus yang pada tahun sebelumnya sama sekali tidak terdapat kasus klinis JE, dimana 17 diantaranya merupakan warga asli Desa Canggu dan 1 orang merupakan warga negara asing (Dinas Kesehatan Provinsi Bali, 2015).

Imunisasi JE diberikan untuk melindungi dari radang otak karena infeksi virus Japanese Ensefalitis. Kampanye dan introduksi akan di awali di Provinsi Bali (tahun 2017-2018). Kampanye Imunisasi dijadwalkan pada bulan Maret-April 2018 yang dibagi menjadi 2 tahap pelaksanaan yaitu bulan Maret dilaksanakan di PAUD, TK, SD, SMP Se-Provinsi Bali sedangkan bulan April di Posyandu, Pustu, Puskesmas, Rumah Sakit dan Pos Pelayanan Imunisasi JE. Yang menjadi sasaran dalam pemberian imunisasi ini adalah anak pada usia 9 bulan sampai dengan usia kurang dari 15 tahun.

Salah satu upaya untuk peningkatkan pengetahuan masyarakat pada umumnya dan anak sekolah khususnya dapat dilakukan melalui Komunikasi,Informasi dan Edukasi
(KIE). Penyampaian materi pada program KIE dapat dilakukan melalui beberapa metode dan media. Media yang digunakan sangat bervariasi mulai dari yang tradisional yaitu mulut (lisan), bunyi-bunyian (kentongan), tulisan (cetak), sampai dengan elektronik yang modern yaitu televisi dan internet (Notoatmodjo, 2007).

Penelitian yang dilakukan Nurhidayah pada tahun 2016 menyatakan sebagian besar responden memiliki pengetahuan kurang, yaitu sebesar 78,15\%. Sementara itu berdasarkan kejadian JE, 52,94\% penderita JE memiliki pengetahuan kurang dan 81,34\% non JE memiliki pengetahuan kurang pula. Berdasarkan penelitian tersebut, perlu adanya edukasi dan penyuluhan kepada masyarakat terkait bahaya JE. Sejalan dengan program pemerintah melaksanakan kampanye imunisasi untuk anak usia 9 bulan sampai 15 tahun, maka peneliti tertarik untuk meneliti mengenai pengaruh pendidikan kesehatan tentang Japanese Encephalitis (JE) terhadap tingkat pengetahuan siswa sekolah dasar di Desa Canggu Kabupaten Badung. Sasaran peneliti merupakan anak sekolah dasar kelas lima dan enam karena usia tersebut merupakan masa perkembangan kognitif kongkrit sehingga sudah dapat menerima informasi dengan baik.

\section{Metode Penelitian}

Penelitian ini merupakan penelitian PreExperimental dengan desain the one group pretest posttest design. Sampel penelitian adalah anak sekolah dasar kelas 5 dan 6 di Desa Canggu Kecamatan Kuta Utara Kabupaten Badung yang berjumlah 65 sampel. Analisis ini digunakan untuk melihat perbedaan antara variabel pengetahun sebelum dan variabel pengetahuan sesudah diberikan intervensi dengan menggunakan uji Wilcoxon.

\section{Hasil dan Pembahasan}

Berdasarkan Tabel 1 menunjukan sebagian besar responden berumur 12 tahun (60\%), dan berjenis kelamin perempuan sebanyak 37 responden $(56,9 \%)$. Tabel 2 menunjukan sebagian besar pengetahuan responden 
sebelum diberikan pendidikan kesehatan tentang Japanese Encephalitis memiliki pengetahuan kurang yaitu sebanyak 40 responden $(61,5 \%)$. Tabel 3 menunjukan sebagian besar responden memiliki pengetahuan baik setelah diberikan pendidikan kesehatan tentang Japanese
Encephalitis yaitu sebanyak 40 responden $(61,5 \%)$. Tabel 4 menunjukan nilai $\mathrm{p}$ value $0,014<0,05$ yang artinya ada pengaruh pendidikan kesehatan tentang Japanese Encephalitis terhadap tingkat pengetahuan siswa sekolah dasar di Desa Canggu, Kabupaten Badung, Bali.

Tabel 1. Karakteristik Responden

\begin{tabular}{ccc}
\hline Karakteristik & $\mathbf{f}(\mathbf{n}=\mathbf{6 5})$ & \% \\
\hline Umur Responden & 26 & \\
$-\quad$ 11 tahun & 39 & 40,00 \\
$-\quad$ 12 tahun & & 60,00 \\
\hline Jenis Kelamin & 28 & \\
$-\quad$ Laki-laki & 37 & 43,1 \\
$-\quad$ Perempuan & & 56,9 \\
\hline
\end{tabular}

Tabel 2. Pengetahuan Pre Test Responden tentang Japanese Encephalitis

\begin{tabular}{|c|c|c|}
\hline \multirow{2}{*}{\multicolumn{3}{|c|}{$\begin{array}{l}\text { Variabel } \\
\text { Pengetahuan }\end{array}$}} \\
\hline & & \\
\hline - Kurang & 40 & 61,5 \\
\hline - $\quad$ Baik & 25 & 38,5 \\
\hline
\end{tabular}

Tabel 3. Pengetahuan Post Test Responden tentang Japanese Encephalitis

\begin{tabular}{ccc}
\hline Variabel & F (n=65) & \% \\
\hline Pengetahuan & & \\
$-\quad$ Kurang & 25 & 38,5 \\
$-\quad$ Baik & 40 & 61,5 \\
\hline
\end{tabular}

Tabel 4. Analisis Pengaruh Pengetahuan tentang Japanese Encaphalitis

\begin{tabular}{lcc}
\multicolumn{1}{c}{ Variabel } & p-value & Nilai Z \\
\hline $\begin{array}{l}\text { Pengetahuan sebelum dan } \\
\text { sesudah }\end{array}$ & 0,014 & $-2,466$ \\
\hline
\end{tabular}

\section{Pengetahuan Responden sebelum diberikan Pendidikan Kesehatan tentang Japanese Encephalitis}

Berdasarkan hasil penelitian, diperoleh pengetahuan responden sebelum diberikan edukasi tentang Japanese Encephalitis sebanyak $61,5 \%$ responden memiliki pengetahuan kurang dan sebanyak 38,5\% responden memiliki pengetahuan baik. Notoatmodjo (2007), berpendapat bahwa ada beberapa faktor yang mempengaruhi pengetahuan seseorang seperti pendidikan, media massa/ informasi, sosial budaya dan ekonomi, lingkungan, pengalaman dan umur. Pendidikan mempengaruhi proses belajar, makin tinggi pendidikan seseorang makin mudah orang tersebut untuk menerima informasi, semakin banyak informasi yang masuk semakin banyak pula pengetahuan yang didapatkan. Pengetahuan sangat erat kaitannya dengan pendidikan dimana diharapkan seseorang dengan pendidikan tinggi, maka orang tersebut akan semakin luas pula pengetahuannya, namun perlu ditekankan bahwa seorang yang berpendidikan rendah tidak berarti mutlak berpengetahuan rendah pula. Peningkatan pengetahuan tidak mutlak diperoleh di pendidikan formal, akan tetapi juga dapat diperoleh pada pendidikan non formal. Pengetahuan seseorang tentang sesuatu obyek juga mengandung dua aspek yaitu aspek positif dan negatif. Kedua aspek inilah yang akhirnya akan menentukan sikap 
seseorang terhadap obyek tertentu, semakin banyak aspek positif dari obyek yang diketahui, akan menumbuhkan sikap makin positif terhadap obyek tersebut.

Pengetahuan siswa sebagian besar kurang sebelum mendapatkan pendidikan kesehatan tentang Japanese Encephalitis karena siswa di Sekolah Dasar di Desa canggu belum optimal mendapatkan pengetahuan atau pendidikan kesehatan terkait penykit Japanese Encephalitis. Siswa Sekolah Dasar di Desa Canggu hanya mendapatkan informasi tentang penyakit Japanese Encephalitis dari pelajaran di sekolah. Kurangnya pengetahuan yang dimiliki oleh siswa Sekolah dasar di Desa Canggu berdampak pada kurangnya pemahaman tentang penanganan serta tanda gejala penyakit Japanese Encephalitis sehingga siswa kurang memahami tanda gejala penyakit Japanese Encephalitis. Hal ini sejalan dengan penelitian yang dilakukan oleh Sulastri (2018) tentang pengaruh Pendidikan Kesehatan terhadap Sikap dan Perilaku Personal Hygiene Gigi dan Mulut pada Anak Usia Sekolah di SD Negeri Payung. Hasil penelitian menunjukkan sebelum diberikan pendidikan Kesehatan personal hygiene gigi dan mulut, mayoritas siswa SD Negeri Payung memiliki perilaku tidak baik sebesar $69,4 \%$ sedangkaan yang berperilaku baik sebesar 30,6\%.

\section{Pengetahuan Responden setelah diberikan Pendidikan Kesehatan tentang Japanese Encephalitis}

Berdasarkan hasil penelitian, diperoleh pengetahuan responden setelah diberikan edukasi tentang Japanese Encephalitis sebanyak $61,5 \%$ responden memiliki pengetahuan baik dan sebanyak 38,5\% responden memiliki pengetahuan kurang. Notoatmodjo (2007), berpendapat bahwa salah satu faktor yang mempengaruhi pengetahuan seseorang adalah media massa/ informasi. Informasi yang diperoleh baik dari pendidikan formal maupun non formal dapat memberikan pengaruh jangka pendek (immediate impact) sehingga menghasilkan perubahan atau peningkatan pengetahuan.
Majunya teknologi akan tersedia bermacammacam media massa yang dapat mempengaruhi pengetahuan masyarakat tentang inovasi baru, sebagai sarana komunikasi, berbagai bentuk media massa seperti televisi, radio, surat kabar, majalah, penyuluhan dan lain-lain mempunyai pengaruh besar terhadap pembentukan opini dan kepercayan masyarakat tentang suatu hal sehingga memberikan landasan kognitif baru bagi terbentuknya pengetahuan terhadap hal tersebut.

Hal ini sejalan dengan penelitian oleh Suhertusi, dkk (2014) tentang pengaruh media promosi kesehatan tentang ASI Ekslusif terhadap peningkatan pengetahuan ibu di wilayah kerja Puskesmas Lubuk Bedalung Padang tahun 2014 yang menemukan bahwa ada peningkatan pengetahuan ibu seblum dan sesudah diberi promosi kesehatan dengan media leaflet dan media film. Media film lebih efektif meningkatkan pengetahuan disbanding dengan media leaflet.

\section{Pengaruh Pendidikan Kesehatan terhadap Tingkat Pengetahuan Siswa Sekolah Dasar tentang Japanese Encephalitis}

Berdasarkan tabel di atas, diperoleh nilai $\mathrm{p}$ value $0,014 \leq 0,05$ yang artinya ada pengaruh pendidikan kesehatan tentang Japanese Encephalitis terhadap tingkat pengetahuan siswa sekolah dasar di Desa Canggu, Kabupaten Badung, Bali. Pendidikan kesehatan adalah suatu kegiatan atau upaya terencana untuk menciptakan atau mengubah pandangan, sikap dan perilaku dari sasaran pendidikan (individu, keluarga, kelompok dan masyarakat) agar mampu memelihara, meningkatkan, dan menyelesaikan masalah kesehatan.

Pengetahuan adalah hasil penginderaan manusia, atau hasil tahu seseorang terhadap obyek melalui indera yang dimilikinya (mata, hidung, telinga, dan sebagainya), pada dasarnya manusia selalu ingintahu yang benar tentang suatu hal, untuk memenuhi rasa ingin tahu ini, manusia sejak zaman dahulu telah berusaha mengumpulkan pengetahuan. Pengetahuan pada dasarnya terdiri dari 
sejumlah fakta dan teori yang memungkinkan seseorang untuk dapat memecahkan masalah yang dihadapinya. Pengetahuan tersebut diperoleh baik dari pengalaman langsung maupun melalui pengalaman orang lain (Notoatmodjo, 2005).

Penelitian yang dilakukan oleh Lisa, A dkk tentang Hubungan Tingkat Pengetahuan, Pendidikan dan Sikap dengan Partisipasi Ibu Rumah Tangga dalam Pencegahan Wabah DBD di Kecamatan Kuta Alam Banda Aceh pata tahun 2015 menemukan bahwa terdapat hubungan tingkat pengetahuan, pendidikan dan sikap dengan partisipasi ibu rumah tangga dalam pencegahan wabah DBD di kecamatan Kuta Alam Banda Aceh. Penelitian lain juga dilakukan oleh Wiskha, D.F, dkk tentang Pengaruh Pendidikan Kesehatan terhadap Perubahan Tingkat Pengetahuan dan Sikap Masyarakat tentang Demam Berdarah Dengue di Desa Trosono kabupaten Magetan menemukan bahwa terdapat pengatuh pendidikan kesehatan terhadap perubahan pengetahuan dan sikap masyarakat tentang demam berdarah dengue di Desa Trosono Kabupaten Magetan.

Penelitian ini senada dengan penelitian yang dilakukan oleh Santoso, dkk (2013) tentang faktor risiko filariasis, hasil penelitian menunjukkan $61,9 \%$ kasus memiliki pengetahuan rendah dan $66,5 \%$ bukan kasus memiliki pengetahuan rendah pula.Walaupun dengan perkembangan teknologi yang begitu pesatnya yang memungkinkan masyarakat bisa mengakses informasi terkait JE, namun penyakit JE ini masih terdengar asing di telinga masyarakat dan masih banyak masyarakat yang belum terpapar oleh informasi terkait JE. Hal ini sesuai dengan pendapat Notoatmodjo (2007) bahwa pengetahuan lebih banyak bergantung pada paparan informasi mengenai suatu hal.

Hal ini sesuai dengan penelitian yang dilakukan oleh Rahmawati Mustamin yang menyebutkan bahwa terdapat perbedaan tingkat pengetahuan yang signifikan tingkat pengetahuan sebelum dan sesudah intervensi pada siswa. Selain itu, Penelitian Siti Aisah (2008) menghasilkan perbedaan signifikan rata-rata pengetahuan sebelum dan setelah intervensi edukasi kelompok sebaya, demikian juga perbedaan signifikan rata-rata pengetahuan antara kelompok perlakuan dan kontrol. Hal ini juga didukung dalam penelitian Wati yang menunjukkan adanya pengaruh pemberian pendidikan kesehatan terhadap tingkat pengetahuan remaja putri. Selain itu juga sejalan dengan penelitian Nurhidayat (2012) bahwa setelah penyuluhan terdapat perbedaan pengetahuan pada kelompok kontrol dan intervensi.

Berdasarkan hasil penelitian Rompas, dkk (2014) menyatakan bahwa nilai rata rata sikap siswa remaja di SMK Fajar Bolaang Mongondow Timur sebelum diberikan pendidikan kesehatan yaitu 4,61 dan setelah diberikan pendidikan kesehatan, nilai rata - rata sikap meningkat menjadi 5,73. Dengan demikian dapat dilihat terjadinya peningkatan skor rata - rata sikap remaja setelah pemberian pendidikan kesehatan. Berdasarkan penelitian yang dilakukan oleh Wahdini (2013), yang meneliti Pengaruh Penyuluhan Oleh Tenaga Pelaksana Gizi dengan Metode Ceramah Disertai Media Poster dan Leaflet Terhadap Perilaku Ibu dan Pertumbuhan Balita Gizi Kurang di Kecamatan Tanjung Beringin, dengan kesimpulan bahwa penyuluhan dengan metode ceramah disertai media poster dan penyuluhan dengan metode ceramah disertai media leaflet dapat meningkatkan pengetahuan dan sikap ibu balita.

Hasil penelitian Zulaekah (2012) ini menunjukkan bahwa intervensi pendidikan gizi dua minggu sekali dengan alat bantu booklet secara langsung pada siswa didukung dengan pendidikan gizi pada guru kelas dan orangtua dalam hal ini ibu akan meningkatkan pengetahuan gizi tentang anemia pada anak dari nilai rata-rata $54,11 \%$ menjawab benar menjadi 71,56 \% menjawab benar. Peningkatan pengetahuan yang terjadi pada sampel adalah 17,44 point. Hasil penelitian Kartini dkk., (2001) menunjukkan ada kecenderungan peningkatan pengetahuan, sikap dan praktek pada anak sekolah yang mendapatkan model Komunikasi Informasi dan Edukasi (KIE) dengan pemberian buku tentang anemia. 
Selanjutnya pemberian pendidikan gizi dengan metode partisipasi, ditambah suplementasi tablet besi satu minggu dua kali selama 12 minggu dapat meningkatkan pengetahuan, sikap siswi SLTP tentang anemia (Sakti dkk., 2003).

\section{Simpulan}

Berdasarkan hasil penelitian maka dapat ditarik beberapa kesimpulan yaitu pengetahuan responden sebelum diberikan edukasi tentang Japanese Encephalitis memiliki pengetahuan kurang dan setelah diberikan edukasi tentang Japanese Encephalitis memiliki pengetahuan baik Ada pengaruh pendidikan kesehatan tentang Japanese Encaphalitis terhadap tingkat pengetahuan siswa sekolah dasar di Desa Canggu, Kabupaten Badung, Bali.

\section{Referensi}

Aisah, S., Sahar, J., Hastono, SP. (2010). Pengaruh Edukasi Kelompok Sebaya Terhadap Perubahan Perilaku Pencegahan Anemia Gizi Besi Pada Wanita Usia Subur Di Kota Semarang. Prosiding Seminar Nasional Unimus 2010 : Universitas Muhamadiyah Semarang.

Departemen Kesehatan RI. (2007). Pedoman Tatalaksana Kasus dan Pemeriksaan Laboratorium Japanese Encephalitis di Rumah Sakit. Direktorat Jenderal Pengendalian Penyakit dan Penyehatan Lingkungan, Jakarta.

Kartini, A., Fatimah, S., Nugraha, P., Rahfiludin, MZ. (2001). Uji Coba Model KIE (Komunikasi, Informasi, dan Edukasi) Dalam Upaya Penanggulangan Anemia Anak Sekolah. Laporan Akhir. Bappeda Kota Semarang Kerjasama dengan Pusat penelitian Kesehatan. Lembaga Penelitian Kesehatan Universitas Diponegoro Semarang.

Kemenkes, RI. (2013). Pedoman Pengendalian Japanese Encephalitis. Jakarta : Kementrian Kesehatan RI.
Najmah. (2015). Epidemiologi Untuk Mahasiswa Kesehatan Masyarakat. Jakarta: PT Raja Grafindo Persada.

Notoatmodjo, S. (2007). Promosi Kesehatan dan Ilmu Perilaku. Jakarta : Rineka Cipta.

Nurhidayah. (2016). Kondisi Lingkungan, Pengetahuan, Sikap dan Perilaku Pencegahan Japanese Encephalitis di Daerah yang Pernah Mengalami KLB. Skripsi : Universitas Udayana.

Nurhidayat, O. (2012). Perbandingan Media Power Point dengan Flip Chart dalam Meningkatkan Pengetahuan Kesehatan Gigi dan Mulut. Jurnal of Public Health. 1(5), 31-35.

Nursalam. (2008). Konsep dan Penerapan Metodologi Penelitian Ilmu Keperawatan. Jakarta: Salemba Medika.

Ompusunggu, S., Hills, SL., Maha, MS., Moniaga, VA., Susilarini, NK., Widjaja, A. (2008). Confirmation of Japanese Encephalitis as an Endemic Human Disease Through Sentinel Surveillance in Indonesia. Am J Trop Med Hyg, 79 (6) : 963-970.

Paramarta, I.G.E., Kari, I.K. \& Sunartini, H. (2009). Faktor Risiko Lingkungan pada pasien Japanese Encephalitis. Sari Pediatri. 10 (5), 308-313

Rampengan., Novi, H. (2016). Japanese Encephalitis. Jurnal Biomedis (JBM), 2 (2). 10-22

Rompas, dkk. (2014). Pengaruh Pendidikan Kesehatan terhadap Tingkat Pengetahuan dan Sikap Remaja tentang Penyakit Menular Seksual di SMK Fajar Bolaang Mongondow Timur. Jurnal Keperawatan. 2 (2), 22-29

Sakti, H., Rachmawati, B., Rahfiludin, MZ. (2003). Pengaruh Suplementasi Tablet Besi dan Pendidikan Gizi terhadap Pengetahuan, Sikap, Praktek tentang Anemi dan Kadar Hemoglobin $(\mathrm{Hb})$ pada Remaja Putri. Media Medika Indonesiana. Fakultas Kedokteran Universitas Diponegoro Semarang. 38 (1), 24-30. 
Santoso, dkk. (2015). Pengetahuan, Sikap dan Perilaku Masyarakat Pasca Pengobatan dan Pengaruhnya terhadap Endemisitas Filariasis di Kabupaten Tanjung Jabung Timur. SPIRAKEL, 7 (1). 14-26.

Suhertusi, B., Desmiwarti., Nurjasmi, E. (2015). Pengaruh Media Promosi Kesehatan Tentang ASI Ekslusif terhadap Peningkatan Pengetahuan Ibu di Wilayah Kerja Puskesmas Lubuk Bedalung Padang tahun 2014. Jurnal Kesehatan Andalas. 4(1), 1722

Sulastri. (2018). Pengaruh Pendidikan Kesehatan Terhadap Sikap dan Perilaku Personal Hygiene Gigi dan Mulut Anak Usia Sekolah di SD Negeri Payung. Jurnal Care. 6 (1), 92-101

Wahdini. (2012). Pengaruh Penyuluhan oleh Tenaga Pelaksana Gizi dengan Metode Ceramah disertai Media Poster dan Leaflet terhadap Perilaku Ibu dan Pertumbuhan Balita Gizi Kurang di Kecamatan Tanjung Beringin Tahun 2010. Skripsi : Universitas Sumatera Utara.

Zulaekah. (2012). Efektivitas Pendidikan Gizi dengan Media Booklet terhadap Pengetahuan Gizi dan Anak SD. Jurnal Kesehatan Masyarakat, 7 (2), 121-128. 